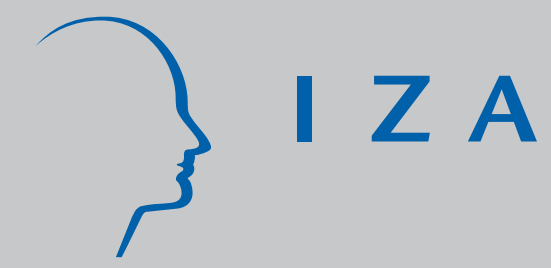

IZA DP No. 788

Immigrants in the UK and in West Germany Relative Income Position, Income Portfolio, and Redistribution Effects

Felix Büchel

J oachim R. Frick

J une 2003 


\title{
Immigrants in the UK and in West Germany - Relative Income Position, Income Portfolio, and Redistribution Effects
}

\author{
Felix Büchel \\ Max Planck Institute for Human Development, \\ Technical University of Berlin, Free University of Berlin, \\ DIW Berlin and IZA Bonn \\ Joachim R. Frick \\ DIW Berlin
}

Discussion Paper No. 788

June 2003

IZA

P.O. Box 7240

D-53072 Bonn

Germany

Tel.: +49-228-3894-0

Fax: +49-228-3894-210

Email: iza@iza.org

This Discussion Paper is issued within the framework of IZA's research area Mobility and Flexibility of Labor. Any opinions expressed here are those of the author(s) and not those of the institute. Research disseminated by IZA may include views on policy, but the institute itself takes no institutional policy positions.

The Institute for the Study of Labor (IZA) in Bonn is a local and virtual international research center and a place of communication between science, politics and business. IZA is an independent, nonprofit limited liability company (Gesellschaft mit beschränkter Haftung) supported by the Deutsche Post AG. The center is associated with the University of Bonn and offers a stimulating research environment through its research networks, research support, and visitors and doctoral programs. IZA engages in (i) original and internationally competitive research in all fields of labor economics, (ii) development of policy concepts, and (iii) dissemination of research results and concepts to the interested public. The current research program deals with (1) mobility and flexibility of labor, (2) internationalization of labor markets, (3) welfare state and labor market, (4) labor markets in transition countries, (5) the future of labor, (6) evaluation of labor market policies and projects and (7) general labor economics.

IZA Discussion Papers often represent preliminary work and are circulated to encourage discussion. Citation of such a paper should account for its provisional character. A revised version may be available on the IZA website (www.iza.org) or directly from the author. 
IZA Discussion Paper No. 788

June 2003

\section{ABSTRACT \\ Immigrants in the UK and in West Germany - Relative Income Position, Income Portfolio, and Redistribution Effects}

Based on data from the BHPS and the GSOEP, we analyse the economic performance of various ethnic groups in the UK and West Germany, as well as the effects of income redistribution on these populations. Taking the indigenous population of each country as the reference category, we find that, as a whole, the non-indigenous population in the UK fares much better than the immigrant population in Germany. However, the range of economic performance across different ethnic groups in the UK is much larger than that in Germany. The German corporatist welfare system is characterised by much stronger redistribution effects than the liberal UK one. Consequently, the relatively low-performing immigrant population in Germany profits more from the redistribution system than immigrants with similar socio-economic attributes in the UK.

JEL Classification: J15, J18, D31

Keywords: immigration, migration policy, income redistribution

Corresponding author:

Felix Büchel

Max Planck Institute for Human Development

Lentzeallee 94

14195 Berlin

Germany

Tel.: +493082406427

Fax: +4930824993

Email: buechel@mpib-berlin.mpg.de 


\section{Introduction ${ }^{1}$}

Most western European countries currently face the problem of low fertility rates and increasing life expectancy. Scientists and politicians are starting to realise that, in the long run, this may severely endanger the welfare system or at least the level of economic well-being in their countries. In this context, selective immigration is considered as a tool that may help to address the problem. This approach, however, is in clear conflict with public opinion-on the whole, immigrants are considered to be an economic burden rather than a relief. This persistent prejudice is hard to refute (cf. Simon \& Lynch 1999; Bauer et al. 2000, Fertig \& Schmidt 2001, 2002).

Most research in this specific field focuses on differences between immigrants and the native-born population with respect to the receipt of public benefits (cf. Jensen 1988, Maani 1993, Khoo 1994, Gustman \& Steinmeier 1998, Riphahn 1998, Hu 1998)², but neglects the other side of the cost-benefit calculation, i.e., tax and social security contributions. The question of whether immigrants--or specific subgroups of the immigrant population-tend to enrich or burden the native-born population is an important one. Borjas (1995) believes that the cost-benefit calculation will become a key component of the immigration debate. The crucial question is: "Do (immigrants) consume more services from the public sector than they pay for in taxes?" (Schultz 1998, p. 245). As Bhattarai \& Whalley (1997) clearly point out, this question cannot be answered by analysing only the take-up of public transfers such as welfare benefits. An appropriate approach must consider both the receipt of benefits and the contribution to the tax and welfare system. Ideally, observation periods should cover the full life-cycle of immigrants. However, the analyses reported in most of the existing literature-including the present study--are restricted to rather short observation periods of just a few years, or even to single-year snapshot analyses, although the limitations of such designs are evident (cf. Bonin 2001 for an attempt to overcome these limitations). LaLonde \& Topel (1991) report that immigrants to the USA have lower incomes than the native-born population, but bear this burden for themselves, that is, without any serious effects on the host population resulting from redistribution. Simon (1996) confirms this finding for the US of the 1970s, but shows that for more recent periods the picture is no longer as clear. For Switzerland, Weber \& Straubhaar (1996) report that

immigrants are net payers to the tax and social security system. Gustafsson \& Österberg (2001) note that immigrants tend to burden the public sector budget upon arrival in Sweden, but that after a few years this is no longer the case. However, as Ekberg (1999) points out, the question of whether immigrants on the whole contribute to or benefit 
from the public sector is largely dependent on the age structure of the immigrant population and on the labour market situation, and is therefore subject to change. It should be noted, however, that none of these studies are able to consider the possible indirect effects that immigration may have through its influence on native productivity, wages, and other relevant economic dimensions (cf. e.g. Friedberg \& Hunt 1995). This limitation also applies to the present study.

Clearly, cost-benefit analyses in the context of immigration are strongly influenced by institutional settings, mainly with respect to immigration policy and the structure of the welfare system. As a consequence, it is questionable whether results from one country can be generalised to others, and adopted as guidelines for immigration policy-makers elsewhere, particularly when the respective immigrant populations differ. As such, it would seem valuable to conduct cross-country analyses with comparable data in order to analyse how immigrants fare in different countries given the respective institutional frameworks and controlling for individual characteristics of the immigrants. The analysis presented here focuses on two important west European countries with distinct immigration histories, policies, and welfare regimes, namely the UK and Germany. The aim of the paper is to describe whether (and if so, to what extent) institutional settings such as immigration policy and the structure of the tax and welfare system as a whole influence immigrants' economic performance. A special focus is placed on institutional effects on the performance of various ethnic groups in each country.

\section{Immigration Policy and the Welfare System in the UK and Germany: Stylised Characteristics of Institutional Settings}

\section{Immigration Policy}

Although there are substantial differences between the immigration policies of the UK and Germany, some important similarities can be identified "The immigration policies of the UK have been driven primarily by political, rather than economic concerns" (Wheatley Price 2001a, p. 195). Since the 1973 stop to the worker-recruitment policy of the 1960s and early 1970s (Anwerbe-Stopp), the same has been true of Germany. In both countries, there are certain groups that have privileged immigration status owing to historical responsibilities--in the UK, those from (former) British colonies and dominions, and in Germany, people of German ancestry (Aussiedler) moving back to Germany from former Eastern bloc countries (cf. Zimmermann 1999 for background 
information about this specific group). In both countries, family-related network migration accounts for a large proportion of the non-indigenous population. In this context, both countries experience an inflow of persons with human capital endowments that are less transferable to the demands of the host country's labour market. Last but not least, both countries implement strong immigration controls in order to discourage refugees and asylum seekers from crossing their borders, on the basis that these groups are without doubt those most likely to burden the welfare state.

Beyond these similarities, there are some country-specific differences which are worthy of note. In contrast to Germany, the UK has a tradition of attracting not only less educated immigrants, but also highly skilled workers. Some of the Indians and many of the Asians immigrating to the UK import above-average skills (cf. Bell 1997), whereas highly qualified immigrants are comparatively rare in Germany. The sharpest contrast, however, is that racial disparities do not play an important role in the German immigration discussion (disregarding for a moment the very specific situation of the relatively small group of refugees and asylum seekers in Germany, who are only tolerated on a temporary basis). This is simply because the number of non-white permanent immigrants to Germany is marginal. For background information about immigration policy and the social structure of immigration in the UK, see e.g. Hatton \& Wheatley Price (1999); for analogous information about Germany, see e.g. Rotte (1998). For recent changes in immigration policy and the structure of immigration, see OECD (2001, p. 185ff. [Germany] ${ }^{3}$ and p. 264ff. [UK]).

\section{Welfare System}

The UK is considered to belong to the group of 'liberal' welfare states characterised by relatively low taxes, low means-tested assistance, and modest universal transfers and social insurance plans (cf. Esping-Andersen 1990). Benefits cater mainly to a low income clientele, mainly to prevent the (very) 'worst case' scenario (cf. Hills 1995 for an overview). Although policy-makers are still rather reluctant to fully adopt EU social policy standards in the UK, the influence of the European Union tends to steer the British welfare system somewhat further away from the classic 'liberal' systems such as the US.

Germany, in contrast, is considered to be a typical representative of the 'corporatist' welfare system, in which the male breadwinner model is supported. Well-established public pension and health care schemes as well as the unemployment insurance system 
protect against "traditional" income risks. Redistribution effects in this type of welfare regime are expected to be rather large when compared to more liberal systems, especially in terms of poverty protection. Income inequality is thus rather low in this system, with its extended welfare programs and relatively high taxes (cf. Ankrom 1993, Ervik 1998).

\section{Data and Methods}

\subsection{Data}

The UK section of our analysis is based on the British Household Panel Study (BHPS). This representative household panel survey, directed by the Institute for Social and Economic Research (ISER) at the University of Essex, was initiated in 1991. Starting with 5,500 households and 10,300 individuals who are re-interviewed yearly, it has become one of the most important databases for social researchers using British data (for further details, see Taylor, 1998, or http://www.iser.essex.ac.uk/bhps). In the present study, we use data from 1995 to 1998. Because BHPS respondents are asked to provide information on their income for the 12-month period preceding the interview, our analysis covers respondents' income for the period from September 1, 1994 to August 31, 1998 (for documentation of annual income data based on the BHPS, see Bardasi et al. 1999).

The German part of the analysis is based on representative microdata from the German Socio-Economic Panel (GSOEP), likewise an ongoing panel survey with a yearly reinterview design. The starting sample in 1984 was of similar size to that of the BHPS. In contrast to the BHPS, the immigrant population was over-sampled in the GSOEP, thus facilitating analyses of this specific population (for further details, see SOEPGroup, 2001, Wagner et al., 1993, or http://www.diw.de/english/sop). Because almost no immigrants are resident in Eastern Germany, and because East German income structures still differ markedly from West German ones, we restrict our analysis to West Germany. Furthermore, we exclude refugees and asylum seekers because of their very specific income situation and their--at best--restricted coverage in the BHPS. We use GSOEP data collected from 1995 to 1999, including the new "immigrant" sub-sample initiated in 1994/95 (Burkhauser et al. 1997). In terms of retrospective income information, we therefore analyse income years 1994 to $1998 .{ }^{4}$ 
In order to control for differences in initial sampling probabilities and selective attrition over time, we apply appropriate weighting factors to all descriptive analyses for both samples (for technical details of the GSOEP, see Haisken-DeNew \& Frick 2001; for the BHPS, see http://www.iser.essex.ac.uk/bhps/doc/index.html [Section V]). In order to reduce the impact of different age distributions, ${ }^{5}$ and to focus on the economic performance and capacity for self-support in different ethnic subgroups, we generally restrict our analyses to those living in households with a head of prime age (20 to 60 years). ${ }^{6}$

\subsection{Level of Analysis and Definition of Ethnic Groups}

The unit of analysis is the individual in his or her respective household context. Households are categorised into different ethnic groups according to the ethnicity of the adult household members (aged 17 and over). After categorisation at the household level, all members of a household (including dependent children) are assigned the same ethnicity status, regardless of their legal nationality.

Ethnic subpopulations in the UK are tend to be differentiated along race lines (see, for example, Berthoud, 1998). Because there is no German equivalent to this race concept, however, in the present paper we distinguish according to the region of origin of the non-indigenous population: i) native-born persons with an immigrant background ('immigrants' in the broader sense); ${ }^{7}$ ii) Commonwealth citizens from India; iii) Commonwealth citizens from Africa and the Caribbean; ${ }^{8}$ iv) Commonwealth citizens from Pakistan and Bangladesh; v) citizens of other European Union countries; vi) citizens of (other) western industrialized countries; vii) other (non-indigenous) persons. The reference group is the indigenous population of native-born whites. Note that this approach also covers the race aspect to a large degree.

In West Germany, we distinguish the following non-indigenous groups: i) native-born non-Germans; ii) ethnic Germans (Aussiedler) from former Soviet Republics; iii) ethnic Germans (Aussiedler) from Poland and Romania; iv) citizens of Turkey and the former Yugoslavia (the major non-EU countries from which "guest workers" were formerly recruited); v) citizens of European Union countries; vi) citizens of (other) western industrialized countries; vii) other (non-indigenous) persons. Here, the reference group is the indigenous population of native-born Germans. Based on this definition of ethnic groups, Table 1 shows the respective proportions of each subgroup in each national 
sample. While about $13 \%$ of the UK population lives in non-indigenous households (with prime-aged heads), the figure rises to $22 \%$ in West Germany.

In our regression models, we include further information on the assimilation status of immigrants. We distinguish between so-called 'non-mixed' and 'mixed' immigrant households. In 'non-mixed' households, all adults in the household are immigrants, whereas in 'mixed' (immigrant) households, at least one adult is a member of the indigenous population. The latter household composition is assumed to reflect a higher degree of integration of the immigrant member(s) of the household. In addition, we use a standard indicator to measure the ongoing assimilation of immig rants, namely number of years since migration.

\subsection{Income Components, Relative Income Positions, and Redistribution Measures}

Although we analyse income at the individual level, income information is calculated at the household level. The assumption underlying this approach is that all members of a specific household pool their resources and share the utility of a given household income. Consequently, information about the various (equivalent) income components of a specific household is ascribed to all members of that household, regardless of age or individual income performance. In order to adjust for differences in household size and composition, we apply the modified OECD equivalence scale, which gives weights of 1.0 to the head, 0.5 to other a dult household members, and 0.3 to children. In order to reduce the effect of extreme income outliers, we apply a bottom trimming by eliminating all households with post-government incomes of less than 600 GBP or 1200 DM, respectively. ${ }^{9}$ Finally, after deflating all income measures to 1995 national currencies, we pool the observations across all analysable cross-sectional years in the second half of the 1990s.

Given our interest in differences between the immigrant and indigenous populations, we analyse the following income components for each of the subgroups described above: i) employment income; ii) capital income (including imputed rent for owner-occupied housing); iii) private transfers ${ }^{10}$. The sum of these three components represents pregovernment (or market) income. Adding iv) old age pensions and v) public transfers, ${ }^{11}$ and subtracting vi) taxes and social security contributions finally yields our measure of post-government income. Table 1 presents basic data on cross-ethnic differences in preand post-government income, as well as on income inequality. 
- please insert Table 1 about here --

With only a few exceptions, standard income distribution features emerge for the various subpopulations observed in the two countries. First, the distributions of pre- and post-government income are skewed to the right; i.e., the median is to the left of the mean. Secondly, because our sample was restricted to households with prime-aged heads, average pre-government income levels exceed post-government income levels, with a high proportion of income being paid as tax. The cross-country comparison reveals that the impact of redistribution is markedly higher in Germany, especially when the average amounts of public transfers received and taxes and of social security contributions paid are also taken into account (not shown in this Table). As far as income inequality as measured by the Gini coefficient and the Theil index is concerned, pre- and post- government incomes are less equally distributed in the UK than in Germany. While this also applies to the respective indigenous populations in the crosscountry comparison in the cross-country comparison, it emerges that inequality among the non-indigenous UK population clearly exceed inequality among the reference group of the native born white population. This does not hold for Germany, where inequality measures for immigrants and foreigners do not differ to any great extent from those of native born Germans. The same picture emerges when considering single ethnic groups.

For the purposes of cross-country comparability, the analyses below are based on standardised income components, where individual income is related to the respective mean of the total population in each country (total mean $=100 \%$; for Germany: West Germany). The effect of redistribution is measured by subtracting the relative income position based on pre-government income from that based on post-government income for each individual. This yields a metric measure which is positive (negative) for those who improve (worsen) their income position as a result of the redistribution process. 


\section{Empirical Results}

\subsection{Relative Income Position in Various Types of Income}

As starting point, we compare the rehtive income positions within each of the analysed income components by ethnic group. We focus on both aggregates (market income, non-market income, taxes and social security contributions) and individualcomponents.

$U K$

In the UK, immigrants from the European Union, other western industrialized countries, and other non-Commonwealth countries (mainly Asian countries) show substantially higher pre-government incomes than the native-born white population, whereas those who migrated from India exhibit income levels fairly similar to those of the indigenous population ( $1^{\text {st }}$ panel of the UK part of Table 2 ). In contrast, the economic performance of those who moved to the UK from African and Caribbean Commonwealth countries, and especially of immigrants from Pakistan and Bangladesh, is clearly below average. On average, the latter receive only $42 \%$ of the mean pre-government income of the native-born white population. Native-born non-whites also perform less well than native-born whites $(-21 \%)$. This may be interpreted as evidence for the hypothesis that fully integrating immigrants into their host society is a long-term task. Overall, even when including native-born non-whites, the economic performance of immigrants to the $\mathrm{UK}$ is similar to that of the indigenous population.

- please insert Table 2 about here --

Breaking down the total pre-government income into different components shows that pre-government income consists largely of employment income. Immigrants from the European Union, other western industrialized countries, and other non-Commonwealth countries have above-average capital incomes, as do Indians, who are significant outperformers in this respect ( $+62 \%$ on the UK population average). In sharp contrast, native-born non-whites, immigrants from African and Caribbean Commonwealth countries, and those from Pakistan and Bangladesh receive hardly any income from capital. However, corresponding to the picture that emerged for total pre-government income, even when including native-born non-whites, the average capital income of 
immigrants to the UK is similar to that of the indigenous population The same does not hold for private transfers. Almost all immigrant groups --including native-born nonwhites--enjoy substantially higher levels of private transfer than the native-born white population. Indians form the only exception here, receiving by far the least in private transfers. This is consistent with the finding that this group enjoys exceptionally high capital incomes. It can be assumed that private transfers within the family represent an important alternative to public transfers in a liberal welfare system, helping to prevent low-income families from falling into poverty. However, it must be noted that on average this income component does not exceed five percent of post-government income for any of the ethnic groups considered in the UK analysis.

To gain a better insight into the relevance and structure of non-market income received by immigrants ( $2^{\text {nd }}$ panel of Table 2$)$, we separate old age pensions from public benefits. Because our sample is restricted to people living in households with prime-age heads, the incidence of the former income source is of course very limited, so we concentrate here on income from public benefits. Overall, we observe a similar level of public benefit receipt among native-born whites and the immigrant population as a whole. However, large variations in the magnitude of this income source were found across groups: native-born non-whites receive much higher benefits than native-born whites $(+57 \%)$, as do immigrants from African and Caribbean Commonwealth countries $(+71 \%)$ as well as Pakistanis and Bangladeshis $(+61 \%)$. On the other hand, the level of public benefits received by immigrants from the European Union, and, in particular, from India, 'other' Western industrialized countries, and other non-Commonwealth countries is remarkably low (about $-30 \%$ in the latter three groups).

In general, the pattern of contributions to the tax and social security system ( $3^{\text {rd }}$ panel of Table 2) reflects the pattern observed for pre-government income. In view of their pregovernment income pos ition, Indians contribute less than average, whereas immigrants from the European Union and other western industrialized countries contribute more than average. These deviations are not strongly pronounced, however.

Consequently, the group-specific levels of post-government income $\left(4^{\text {th }}\right.$ panel of Table 2) are similarly distributed as the levels of pre-government income. The poor situation of native-born non-whites (with only $79 \%$ of the national average income), however, improves only marginally (to 84\%) following the transfer of fairly large amounts of non-market incomes. One should bear in mind, however, that this group is considerably 
younger (average age of household head: 36 years) than the remaining population (where the average age of the household head is 41 years). As such, market income (employment and capital income) is more likely to be relatively low.

\section{West Germany}

In West Germany, a very different picture emerges. In line with results presented in the existing literature (see, e.g., Dustmann 1993; Bauer \& Zimmermann 1997; Schmidt 1997; Dustmann \& Schmidt 2000), immigrants show much lower pre-government incomes than native-born Germans (-23\% on the West German population average; $1^{\text {st }}$ panel of the West German part of Table 2). This can be attributed to the low-performing groups of Aussiedler, immigrants from Turkey and the former Yugoslavia, and 'other' (non-industrialized) countries. Contrary to the situation in the UK, native-born foreigners enjoy pre-government income levels similar to those of the indigenous population. The only non-indigenous group that outperforms native-born Germans in pre-government incomes is that of immigrants from (non-EU) Western industrialized countries $(+16 \%)$. In Germany, as well as in the UK, employment incomes constitute the major part of pre-government income. In contrast to the UK, however, the employment incomes of immigrants to Germany do not keep pace with those of the indigenous population, but remain about $25 \%$ lower. A similar situation is found for capital income. The returns on the smaller capital stock of immigrants to Germany are very low compared to those of native-born Germans; the immigrants' average capital income is not even half that of the reference group. ${ }^{12}$ Another striking difference to the UK emerges in the structure of private transfers. Whereas this income component was more than twice as high among UK immigrants than in the indigenous population, it is only half as high in Germany. Ethnic networks providing mutual support seem to be much more common in the UK than in Germany. It is likely that this notable divergence between the two countries under analysis reflects differences in the financial dependencies of low-income groups on friends and relatives, which in turn reflect the different institutional settings of the respective welfare systems.

When focusing on public benefits as the most relevant component of non-market incomes ( $2^{\text {nd }}$ panel of the West German part of Table 2), we again find marked differences between the UK and the German immigrant populations relative to the respective indigenous populations. In total, UK immigrants draw a similar level of public benefits as do native-born whites. In Germany, immigrants receive 30\% more from public transfers than do native-born Germans. Aussiedler from former Soviet 
Republics receive the highest levels of public benefits $(+63 \%$ on the West German population average). The only notable exceptions here are EU migrants and native-born foreigners. Overall, these findings confirm the findings of researchers such as Castranova et al. (2001): that immigrants to Germany are more dependent on public transfers than the native-born population.

The distribution of taxes and social security contributions in West Germany ( $3^{\text {rd }}$ panel of the West German part of Table 2) is similar to that observed for pre-government incomes, with one exception: native-born foreigners make higher contributions than expected. ${ }^{13}$

Summing up, the results presented in this section show a much wider heterogeneity in the economic performance of UK immigrants than in that of immigrants to West Germany. In the UK, the economic performance of the immigrant population as a whole is similar to that of the indigenous population, and some groups of immigrants substantially outperform the native population. On the other hand, some groups, such as Pakistanis and Bangladeshis, were shown to live in very poor conditions. In contrast, German immigrants were found to have a generally low market performance.

\subsection{The Structure of Post-Government Income ("Portfolio")}

We now turn to our income portfolio analysis, in which we calculate the various income components as a share of total post-government income for each ethnic group, i.e., the ir "portfolio structure". We interpret high (low) shares of market income and large (small) losses in the redistribution process as indicators for a high (low) degree of selfsupporting capacity in the respective subgroup (Table 3 ).

In the UK, the total non-indigenous population shows a similar post-government income structure to the indigenous reference group. Market income represents about $100 \%$ of post-government income, about $20 \%$ of the income portfolio comes from nonmarket incomes (in this age group, mainly public benefits) and about the same share is deducted for taxes and contributions to the social security system. Again, however, there is substantial variation within the non-indigenous population. Among native-born non-whites, as well as immigrants from African and Caribbean Commonwealth 
countries, and particularly those from Pakistan and Bangladesh, market incomes play a much smaller role in the structure of the income portfolio than in the other groups. Once again, the Pakistani and Bangladeshi population is the worst off. Their market income constitutes only two thirds of their total income, with public benefits making up more than $40 \%$ of their portfolio. As a consequence, their contribution to the tax and social transfer system is only $10 \%$, and as such much lower than in any other group.

- please insert Table 3 about here --

In Germany, a rather different picture emerges. First of all, the effects of the different institutional settings within the tax and social security system are obvious. While in Germany, $36 \%$ of total income is redistributed by the 'corporatist' welfare state, the corresponding figure for the UK is only $21 \%$. In contrast to the UK, the employment income of the total non-indigenous population represents a similar proportion of postgovernment income as is the case for the native-born German population. However, capital income is of much less importance among the non-indigenous population--with the exception of immigrants from Western industrialized non-EU countries. These show remarkably high shares of market incomes. In contrast to the UK, public benefits make a much larger contribution to the income portfolio of the non-indigenous population than to that of native Germans (17\% vs. 10\%). However, in marked contrast to the UK situation, this income component does not substantially exceed $20 \%$ in any of the population groups under analysis for Germany. 


\subsection{Correlates of Relative Pre -Government Income Position}

In order to evaluate the extent to which the cross-ethnic group differences found in the bivariate analyses can be contributed to ethnicity per se, we estimate multivariate regression models, simultaneously controlling for a range of socio-economic characteristics (head of household's education, age, sex, health status, unemployment experience, and family type). ${ }^{14}$ To avoid systematic correlations between the right-hand variables employed in the estimation result ing from the repeated observation of multiperson households, we restrict our sample to heads of households only. Because data was pooled over several years of observation, we specify random-effects regression models (GLS) to account for individual correlations across time. Dependent variables are $a$ ) the logarithm of "relative pre-government income position" and $b$ ) the absolute "change in the relative income position" following the redistribution process of the tax and welfare system (i.e., the difference between post- and pre-government income). For both regression models, we run four specifications, controlling for the heterogeneity of immigrants in various aspects--region of origin, years since migration, and assimilation status (measured in terms of 'mixed' or 'non-mixed' household).

Simultaneously, we control for a range of socio-economic status measures which are known to be linked to income risks (e.g., number of children, unemployment, health impairments, etc.). We are explicitly interested in differences between the indigenous and non-indigenous populations. To save table space, however, we will only present parameter estimates for immigration-specific covariates (full results are available from the authors upon request). ${ }^{15}$ Information about the distribution of all variables used in the models can be found in Table 4.

- please insert Table 4 about here --

\section{$U K$}

We start by examining the non-indigenous population in the UK (upper panel of Table 5, column 1). The multivariate regression provides support for the results of our bivariate analysis, indicating that the labour market performance of the non-indigenous UK population is similar to that of the indigenous population; i.e., there are no significant differences between the two groups. Results for the control variables show 
the pattern expected on the basis of labour market research (see, e.g., Oxley et al. 2001): Compared to the reference group of couples without children, each additional child reduces market income, this effect being much stronger for lone parents with their reduced earnings capacity. We also confirm the typical age profile, with income decreasing at higher ages, as well as a positive effect for households headed by males, distinct educational differences, and a negative impact of impaired health status and recent unemployment. All these effects are highly significant. However, we do not find any time effect in our pooled data, indicating that income levels in the UK remained stable over the observation period.

When further differentiating ethnicity by controlling for 'non-mixed' and 'mixed' households in the non-indigenous population (see section 3.2), we find that the latter group in fact has a more successful market performance than the indigenous reference group (column 2). Conversely, the market (mainly employment) incomes of immigrants remaining in a 'non-mixed' ethnic context are $20 \%$ lower than those of the indigenous population. Both of these effects are statistically highly significant and underline the importance of societal integration for immigrants to progress to higher economic levels.

When improving the control of differences in the immigrants' ethnicity and regional origin as well as their duration of stay in the UK (column 3), the positive effect of 'mixed' households persists. Furthermore, we confirm the descriptive findings identifying native-born non-whites, immigrants from African and Caribbean Commonwealth countries and, to an even greater extent, Pakistanis and Bangladeshis as high-risk groups with significantly lower labour market performances than the nativeborn white population. These results are in line with those presented by Wheatley Price (2001a, b). Consistent with our descriptive findings, immigrants from India perform similarly to the indigenous population, even when controlling for their socio-economic background. Notably, though, their group-specific above-average market performance that emerged for immigrants from EU countries in the bivariate analysis seems to be caused by a positive selection with respect to their socio-economic characteristics. When background variables are controlled, EU citizens in fact perform less well than the British indigenous population. More detailed analysis using interaction terms of ethnicity and education showed this effect to be based solely on the very poor performance of those EU migrants with low levels of education (not shown in the tables). When controlling for ethnic origin, the immigrants' duration of stay in the UK 
has no significant effect on their economic performance. This raises the question as to the integration capacity of British society.

Finally, when restricting the analysis to the non-indigenous section of our sample and using 'non-mixed' ethnicity households as a reference category (column 4), we find that 'mixed' ethnicity households are indeed much better off than 'non-mixed' ones. Immigrants from India perform better than the reference group of immigrants from EU countries, and those migrating from non-Commonwealth countries show significantly higher pre-government incomes than EU immigrants, although this effect is only significant at the $10 \%$ level

- please insert Table 5 about here --

West Germany

For Germany (lower panel of Table 5), we find quite a different pattern of results in our first specification (column 1). We confirm the descriptive findings according to which the economic performance of the immigrant population as a whole lags behind that of the indigenous population. In principle, the results for the socio-economic control variables are similar to those found for the UK (not documented in table).

Introducing the 'mixed' immigrant household category (column 2) yields a pattern comparable to the one that emerged for the UK. The non-indigenous population is much worse off than the indigenous one, and those immigrants living in 'mixed' ethnicity households are significantly better off than those in 'non-mixed' ones.

When controlling for ethnic origin in a more detailed manner (column 3), the positive effect of living in 'mixed' ethnicity households persists, as was the case for the UK. In contrast to the findings for the UK, however, we cannot identify any immigrant group that outperforms the indig enous population. Only immigrants from (non-EU) western industrialized countries manage to keep pace with native Germans. All other groups are substantially worse off, particularly both groups of Aussiedler, those migrating from Turkey or the former Yugoslavia, or 'other' countries. Note that this residual category does not consist mainly of Asians, as in the UK, but also of people from Eastern Europe. Furthermore, the longer the duration of stay in Germany, the higher the market 
(mostly employment) incomes--even when simultaneously controlling for age. Although this effect is only significant at the $10 \%$ level, it can be taken as a notable difference to the situation in the UK.

Finally, when restricting the German sample to the non-indigenous population (column 4), our first finding is that the 'mixed' immigrant population indeed performs significantly better than those living in 'non-mixed' contexts, most of whom are probably integrated in closely knit ethnic networks. Distinguishing between different ethnic groups reveals that--compared to the reference group of immigrants from EU countries--native -born foreigners perform similarly, whereas all other immigrant groups (except those from other western industrialized countries) are under-performers in terms of their pre-government income position. When restricting the sample to immigrants, the positive effect of duration of stay is more pronounced than reported in the model for the full sample. Furthermore, the negative effect for the squared duration variable indicates that the positive marginal effects associated with length of residency diminish over time.

\subsection{Correlates of Income Redistribution}

Finally, this section focuses on income redistribution effects as measured by the individual difference between post- and pre-government income position. Negative effects emerging from our regression calculation represent individual declines in the relative income position that result from tax and social security contributions paid on the one hand and public benefits received on the other. Again, we are primarily interested in cross-ethnic differences, and control for the same characteristics as mentioned above (Table 6). These measures of socio-economic status basically deliver

the expected results for both countries: An increasing number of children, lone parenthood, increasing age of the household head, low levels of education, physical impairment, and recent unemployment all display a significant positive relation to the redistribution process, while, on average, households with younger heads, male heads, and highly educated heads pay into the system; i.e., their relative pre-government income position is higher than their post-government one (not documented in Table).

- please insert Table 6 about here -- 
Starting once more with the situation in the UK (upper panel of Table 6, column 1), there is no evidence that the non-indigenous population as a whole profits more from the redistribution process than the indigenous one. However, the second specification (column 2) shows that those living in households of 'mixed' ethnicity contribute significantly more to the system than the indigenous population. Compared to the indigenous population, not a single ethnic group significantly profits from or loses out to the redistribution process when controlling for origin and years since migration (column 3). Those living in households of "mixed' ethnicity are still the "losers" in the redistribution process, though at a somewhat lower level of significance.

When focusing only on the sample of non-indigenous UK inhabitants (column 4), the finding persists that, compared to the immigrant population living in 'non-mixed' ethnic households, those living in 'mixed' households help to finance the system. Surprisingly, there are no significant differences according to ethnicity or region of origin. Immigrants from non-EU western industrialized countries constitute the only exception here, and are net contributors to the system, though this effect is only significant at the $10 \%$ level

Again, results for Germany differ markedly from those for the UK (lower panel of Table 6). Our first specification (column 1) indicates that, compared to the indigenous population, the total immigrant population significantly improves its income position as a result of the German redistribution process. This result is mainly attributable to those living in 'non-mixed' ethnic households (column 2). Those living in 'mixed' ethnic households, in contrast, are found to be net payers. Those immigrant groups with below-average pre-government incomes (Aussiedler, immigrants from Turkey and the former Yugoslavia and other non-western industrialized countries) gain most from redistribution in Germany (column 3).

When restricting the sample to the immigrant population (column 4), it still emerges that those living in 'mixed' immigrant households contribute more to the redistribution capacity of the German welfare state than the reference group of those living in households of 'non-mixed' ethnicity. Again, Aussiedler, immigrants from Turkey and the former Yugoslavia and other non-western industrialized countries profit significantly more than the reference group of EU migrants. In contrast, foreigners born in Germany, but without a German passport, experience significant reductions in their 
relative income position as a result of redistribution. With increasing duration of stay in Germany, immigrants benefit less from redistribution. This is an important result, showing that, ceteris paribus, immigrants to Germany become ever less reliant on the redistribution effects of the welfare system--the longer they stay, the better their market performance and the higher the contributions they make to the tax and social security system. This seems to indicate substantial differences between the assimilation capacity of immigrants and the institutional regulations in the UK and in Germany.

\section{Conclusions}

Our results clearly indicate a more pronounced heterogeneity in the economic performance (capacity) of the non-indigenous population in the UK than that in Germany. In the UK, some ethnic groups even outperform the native-born white population. In Germany, this is only the case for immigrants from non-EU western industrialized countries. This may be explained by the qualification level of the mnindigenous population in Germany: this group still includes a high proportion of the rather low -qualified so-called 'guest workers' hired in the 1960s and early 1970s as well as their descendants. At the lower end of the income distribution, Pakistanis and Bangladeshis in the UK are far worse off than the main risk group in Germany, the ethnic Germans (Aussiedler), most of whom have entered the country since the late 1980s.

In contrast to the situation in the UK, the non-indigenous population in Germany profits from the redistribution process, even when controlling for various measures of socioeconomic status such as educational level, number of children, unemployment, health status, etc. Furthermore, the employment incomes of immigrants to Germany increase markedly during their initial period of residency, and, as a result of this improved economic self-support, their reliance on the receipt of public transfers decreases.

In light of these substantive differences, it is remarkable that in both countries immigrants who live in 'mixed' ethnic households (i.e., at least one adult in the household is a member of the indigenous population) outperform the indigenous population with respect to both pre-government income and contributions to the tax and social security system. This positive effect of the long-term assimilation of immigrants remains very stable across the various specifications of our models. However, we cannot rule out endogeneity problems given that this indicator may also be a cause of 
economic success, as well as a result. Further research based on longitudinal data should provide a deeper insight into this important issue.

Finally, the 'better' or 'less costly' socio-economic structure of the non-indigenous UK population, which is doubtlessly influenced by a stricter immigration policy, in combination with a less sheltering 'liberal' welfare state, leads to fundamental differences in eligibility for and take-up of benefits in the two countries analysed. It appears to be rather difficult to separate these two effects. Future studies need to concentrate on this important issue of cross-national comparative research. 


\section{References}

Ankrom, Jeff A. 1993: An analysis of horizontal and vertical equity in Sweden, the US and the UK. Scandinavian Journal of Economics 95 (1), 119-124

Baker, Michael \& Benjamin, Dwayne 1995: The receipt of transfer payments by immigrants to Canada. In: The Journal of Human Resources 30 (4): 650-676

Bardasi, Elena, Jenkins, Stephen P., \& Rigg, John A. 1999: Documentation for Derived Current and Annual Net Household Income Variables, BHPS waves 1-7. Colchester: ISER (unpublished manuscript)

Bauer, Thomas, Lofstrom, Magnus, \& Zimmermann, Klaus F. 2000: Immigration policy, assimilation of immigrants, and natives' sentiments towards immigrants - Evidence from 12 OECD countries. In: Swedish Economic Policy R eview 7 (2), 11-53

Bauer, Thomas, \& Zimmermann, Klaus F. 1997: Unemployment and Wages of Ethnic Germans. In: Quarterly Review of Economics and Finance 37, 361-377

Bell, Brian D. 1997: The performance of immigrants in the United Kingdom: Evidence from the GHS. Economic Journal 107 (441), 333-344

Berthoud, Richard 1998: The Incomes of Ethnic Minorities. ISER Report 98-1. Colchester: University of Essex, Institute for Social and Economic Research

Bhattarai, Keshab \& Whalley, John 1997: The redistributive effects of transfers. NBER Working paper 6281. Cambridge, MA: National Bureau of Economic Research

Bonin, Holger 2001: Fiskalische Effekte der Zuwanderung nach Deutschland - Eine Generationenbilanz. In: Beihefte der Konjunkturpolitik No. 52, 127-156

Borjas, George J. 1995: Immigration and welfare: 1970 - 1990. Research in labor economics 14, 253-282

Borjas, George J. \& Hilton, Lynette 1996: Immigration and the welfare state. Immigrant participation in means-tested entitlement programs. The quarterly journal of economics 111 (2), 575-604

Burkhauser, Richard V., Butrica, Barbara A.,D aly, Mary C., \& Lillard, Dean R. 2001: The Cross-National Equivalent File: A product of cross-national research. In: Becker, Irene, Ott, Notburga, \& Rolf, Gabriele (Eds.) Soziale Sicherung in einer dynamischen Gesellschaft (Social Insurance in a Dynamic Society). Festschrift für Richard Hauser zum 65. Geburtstag (Papers in Honour of the $65^{\text {th }}$ Birthday of Richard Hauser), Campus, Frankfurt/New York

Burkhauser, Richard V., Kreyenfeld, Michaela, \& Wagner, Gert G. 1997: The German Socio-Economic Panel Study: A Representative Sample of Reunified Germany and its Parts. DIW-Vierteljahrshefte zur Wirtschaftsforschung 66 (1), 7-16

Butrica, Barbara A. 1997: Imputation methods for filling in missing values in the PSID-GSOEP Equivalent File 19801994, Cross-National Studies in Aging. Program Project Paper, Center for Policy Research, The Maxwell School. Syracuse, NY: Syracuse University

Castranova, Edward J., Kayser, Hilke, Frick, Joachim R., \& Wagner, Gert G. 2001: Immigrants, Natives and Social Assistance: Comparable Take-Up Under Comparable Circumstances, In: International Migration Review 35(3), 726-748

Creedy, John, Disney, Richard, \& Whitehouse, Edward 1993: The earnings-related state pension, indexation and lifetime redistribution in the UK. Review of Income and Wealth 39 (3), 257-278

Dustmann, Christian 1993: Earnings adjustment of temporary migrants. In: Journal of Population Economics 6 (2), 153-168

Dustmann, Christian \& Schmidt, Christoph M. 2000: The Wage Performance of Immigrant Women: Full-Time Jobs, Part-Time Jobs, and the Role of Selection. IZA Discussion Paper No. 233. Bonn: IZA

Ekberg, Jan (1999): Immigration and the public sector: Income effects for the native population in Sweden. In: Journal of Population Economics 12, 411-430

Ervik, Rune 1998: The redistributive aim of social policy - A comparative analysis of taxes, tax expenditure transfers and direct transfers in eight countries. Luxembourg Income Study Working paper No. 184. Walferdange (Luxembourg): CEPS/INSTEAD

Esping-Andersen, Gosta 1990: The Three Worlds of Welfare Capitalism. Princeton NJ

Fertig, Michael \& Schmidt, Christoph M. 2001: First- and Second-Generation Migrants in Germany - What Do We Know and What Do People Think. In: Rotte, Ralph \& Stein, Peter (eds.), Migration Policy and the Economy: International Perspectives. Munich : xx-yy

Fertig, Michael \& Schmidt, Christoph M. 2002: The Perception of Foreigners and Jews in Germany - A Structural Analysis of a Large Opinion Survey. IZA Discussion Paper No. 431. Bonn: IZA

Friedberg, Rachel M. \& Hunt, Jennifer 1995: The impact of immigrants on host country wages, employment and growth. In: The Journal of Economic Perspectives 9 (2), 23-44

Gustafsson, Björn \& Österberg, Torun 2001: Immigrants and the public sector budget-accounting. In: Journal of Population Economics 14, 689-708

Gustman, Alan L. \& Steinmeier, Thomas Lee 1998: Social security benefits of immigrants and US born. Cambridge, MA: NBER Working Paper 6478

Haisken-DeNew, John P. \& Frick, Joachim R. (Eds.) 2001: DTC - Desktop Companion to the German SocioEcon omic Panel Study (GSOEP), Version 5.0 - November 2001, Berlin: DIW Berlin 
Hatton, Timothy J. \& Wheatley Price, Stephen 1999: Migration, migrants and policy in the United Kingdom. IZA Discussion Paper No. 81. Bonn: IZA

Hills, John R. 1995: Funding the welfare state. Oxford review of economic policy 11 (3), $27-43$

$\mathrm{Hu}$, Wei-yin 1998: Elderly immigrants on welfare. The Journal of Human Resources 33 (3), $711-741$

Jensen, Leif I. 1988: Patterns of immigration and public assistance utilization, 1970 - 1980. International Migration Review 22 (1), $51-83$

Khoo, Siew -ean 1994: Correlates of welfare dependency among immigrants in Australia. International Migration Review 28 (1), 68-92

LaLonde, Robert J. \& Topel, Robert H. 1991: Immigrants in the American labor market - Quality, assimilation, and distributional effects. In: The American Economic Review 81 (2), 297-302

Little, Roderick J.A. \& Su, Hong-Lin 1989: Item Non-Response in Panel Surveys. In: Kasprzyk, D., Duncan, G., Kalton, G. \& Singh, M. P. (eds.): Panel Surveys. John Wiley, New York: 400-425

Maani, Sholeh A. 1993: Immigrants and the use of government transfer payments. The Australian Economic Review $104,65-76$

OECD (Ed.) 2001: Trends in international migration. Continuing reporting system on migration. Annual Report, 2000 Edition. Paris

Oxley, Howard, Dang, Thai -Thanh, Förster Michael F., \& Pellizzari, Michele 2001: Income inequalities and poverty among children and households with children in selected OECD countries. In: Vleminckx, Koen \& Smeeding, Timothy (eds.): Child well-being, child poverty and child policy in modern nations - What do we know? Bristol, UK: $371-406$

Riphahn, Regina T. 1998: Immigrant participation in the German welfare program. Finanzarchiv 55 (2), 163-185

Rotte, Ralph 1998: Sorties from the fortress - The current system of anti-immigration policies in Germany. IZA Discussion Paper No. 13 Bonn: IZA

Schmidt, Christoph M. 1997: Immigrant performance in Germany - Labor earnings of ethnic German migrants and foreign guest-workers. In: The Quarterly Review of Economics and Finance 37, 379-397

Schultz, Theodore Paul 1998: Immigrant quality and assimilation - A review of the US literature. Journal of Population Economics 11 (2), 239-252

Schwarze, Johannes 1995: Simulating German Income and Social Security Tax Payments Using the GSOEP. CrossNational Studies in Ageing Project Paper No. 19. Syracuse University, Syracuse, NY

Shields, Michael A. \& Wheatley Price, Stephen 1998: The earnings of male immigrants in England - evidence from the quarterly LFS. Applied Economics 30 (9), 1157-1168

Simon, Julian L. 1996: Public expenditures on immigrants to the United States, past and present. Population and Development Review 22 (1), 99-109

Simon, Rita J. \& Lynch, James P. 1999: A comparative assessment of public opinion toward immigrants and immigration policies. International Migration Review 33 (2), 455-467

Smeeding, Timothy M.\& Weinberg, Daniel H. (2001): Toward a Uniform Definition of Household Income. Review of Income and Wealth 47(1): 1-24

SOEP-Group (2001): The German Socio-Economic Panel (GSOEP) after more than 15 years - An overview. Vierteljahrshefte zur Wirtschaftsforschung, 70(1): 7-14.

Taylor, Marcia F. (Ed.) 1998: British Household Panel Survey User Manual. Introduction, Technical Reports and Appendices. Colchester: University of Essex, ESRC

United Nations Population Division 2000: Replacement Migration: Is it a Solution to Declining and Ageing Populations? http://www.undp.org/popin/wdtrends/replamigration.htm, accessed 25. January 2000.

Voges, Wolfgang, Frick, Joachim R., \& Büchel, Felix 1998: The Integration of Immigrants into West German Society - The Impact of Social Assistance. In: Kurthen, Hermann, Fijalkowski, Jürgen, \& Wagner, Gert G. (Eds.): Immigration, Citizenship, and the Welfare State in Germany and the United States - Part A, Vol. 14 (A) of Immigrant Incorporation, Industrial Development and Social Fabric Series of JAI Press Inc., Stamford/Connecticut and London: 159-174

Wagner, Gert G., Burkhauser, Richard V., \& Behringer, Friederike 1993: The English Language Public Use File of the German Socio-Economic Panel Study. Journal of Human Resources 28(2), 429-433.

Weber, René \& Straubhaar, Thomas 1996: Immigration and the public transfer system - Some empirical evidence for Switzerland. In: Weltwirtschaftliches Archiv 132 (2), 330-355

Wheatley Price, Stephen 2001a: The employment adjustment of male immigrants in England. Journal of Population Economics 14, 193-220

Wheatley Price, Stephen 2001b: The unemployment experience of male immigrants in England. Applied Economics 33 (2), 201-215

Zavodny, Madeline 1997: Welfare and the locational choices of new immigrants. In: Economic Review (Federal Reserve Bank of Dallas) 2: 2 - 10

Zimmermann, Klaus F. 1999: Ethnic Germans' Migration Since 1989 - Results and Perspectives. IZA Discussion Paper No. 50. Bonn: IZA 
Table 1: $\quad$ Pre- and Post Government Income and Income Inequality Measures in the UK, 1995-1998 ${ }^{1)}$, and in West Germany, 1995-19992), by Ethnic Group

- Population in Private Households with Head of Prime Age -

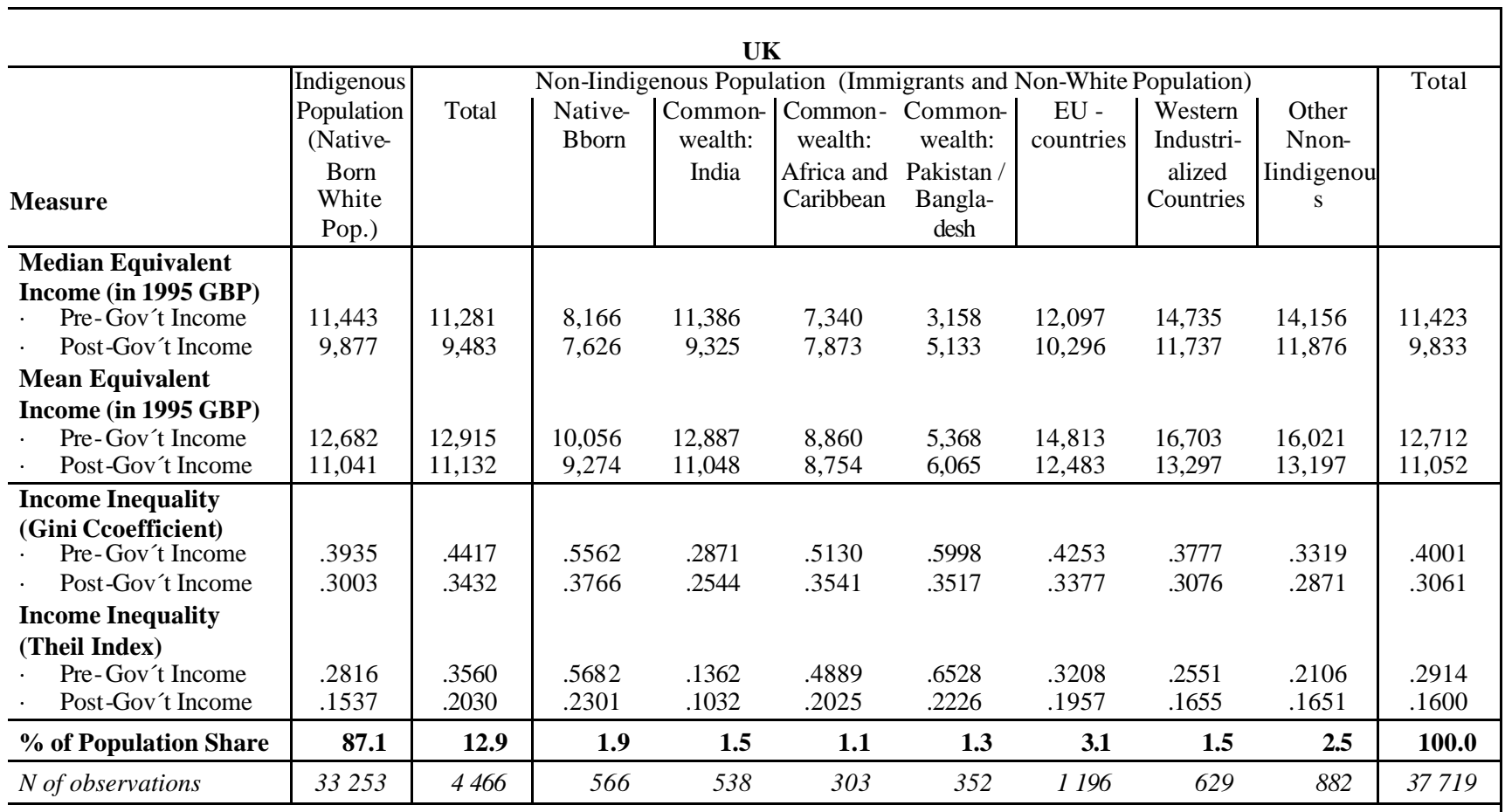

\section{West Germany}

\begin{tabular}{|c|c|c|c|c|c|c|c|c|c|c|}
\hline & Indigenous & \multicolumn{8}{|c|}{ Non-Iindigenous Population (Immigrants and Native-Bborn Foreigners) } & \multirow{2}{*}{ Total } \\
\hline & $\begin{array}{c}\text { Population } \\
\text { (Native- } \\
\text { Born } \\
\text { Germans) }\end{array}$ & Total & $\begin{array}{c}\text { Native- } \\
\text { Bborn }\end{array}$ & $\mid \begin{array}{c}\text { Aussiedler } \\
\text { Former } \\
\text { Soviet } \\
\text { Republics }\end{array}$ & $\begin{array}{l}\text { Aussiedler: } \\
\text { Poland, } \\
\text { Romania }\end{array}$ & $\begin{array}{c}\text { Guest- } \\
\text { workers: } \\
\text { Turkey, } \\
\text { Fformer } \\
\text { Yugoslavia }\end{array}$ & $\begin{array}{c}\text { EU - } \\
\text { countries }\end{array}$ & $\begin{array}{c}\text { Western } \\
\text { Industri- } \\
\text { alized } \\
\text { Countries }\end{array}$ & $\mid \begin{array}{c}\text { Other } \\
\text { Nnon- } \\
\text { Iindigenou } \\
\mathrm{s}\end{array}$ & \\
\hline \multicolumn{11}{|l|}{$\begin{array}{l}\text { Median Equivalent } \\
\text { Income (in } 1995 \text { DEM) }\end{array}$} \\
\hline . Pre-Gov't Income & 45,868 & 31,977 & 39,067 & 27,229 & 31,083 & 27,766 & 41,966 & 61,107 & 34,034 & 42,786 \\
\hline - $\quad$ Post-Gov't Income & 34,837 & 26,025 & 34,838 & 25,243 & 24,173 & 22,738 & 31,792 & 47,997 & 27,531 & 32,821 \\
\hline $\begin{array}{l}\text { Mean Equivalent } \\
\text { Income (in } 1995 \text { DEM) }\end{array}$ & & & & & & & & & & \\
\hline . Pre-Gov́t Income & 51,128 & 37,166 & 47,775 & 32,056 & 36,342 & 30,100 & 46,360 & 56,066 & 38,072 & 48,035 \\
\hline Post-Gov't Income & 38,563 & 29,380 & 31,832 & 27,577 & 27,728 & 24,982 & 34,881 & 42,576 & 29,985 & 36,528 \\
\hline \multicolumn{11}{|l|}{$\begin{array}{l}\text { Income Inequality } \\
\text { (Gini Ccoefficient) }\end{array}$} \\
\hline . Pre-Gov't Income & .3553 & .3795 & .3734 & .3975 & .3622 & .3591 & .3150 & .3025 & .4175 & .3661 \\
\hline - $\quad$ Post-Gov`t Income & .2809 & .2801 & .2751 & .2468 & .2522 & .2434 & .2555 & .2564 & .3338 & .2871 \\
\hline \multicolumn{11}{|l|}{$\begin{array}{l}\text { Income Inequality } \\
\text { (Theil Index) }\end{array}$} \\
\hline . Pre-Gov't Income & .2331 & .2556 & .2316 & .2784 & 2407 & 2330 & .1771 & .2147 & .3191 & 2447 \\
\hline Post-Gov't Income & .1404 & .1327 & .1191 & .1080 & .1190 & .1005 & .1112 & .1428 & .1878 & .1447 \\
\hline$\%$ of Population Share & 77.8 & 22.2 & 0.9 & 3.5 & 1.6 & 7.6 & 4.8 & 0.9 & 2.9 & 100.0 \\
\hline$N$ of observations & 33537 & 17291 & 907 & 1926 & 1127 & 7480 & 4545 & 148 & 1158 & 50828 \\
\hline
\end{tabular}

1) Average of 1994-1997 income years. - 2) Average of 1994-1998 income years.

Source: BHPS; SOEP; Cross-National Equivalent Data File; authors' calculation. 
Table 2: $\quad$ Relative Income Position for Market- and Non-Market Income Components in the UK, 1995-1998 ${ }^{1)}$ and in West Germany, 1995-19992), by Ethnic Group

- Population in Private Households with Head of Prime Age -

UK

\begin{tabular}{|c|c|c|c|c|c|c|c|c|c|c|}
\hline \multirow{3}{*}{ Type of Income } & Indigenous & \multicolumn{8}{|c|}{ Non-indigenous Population (Immigrants and Non-White Population) } & \multirow[t]{2}{*}{ Total } \\
\hline & $\begin{array}{c}\text { Population } \\
\text { (Native- } \\
\text { Born } \\
\text { White } \\
\text { Pop.) } \\
\end{array}$ & Total & $\begin{array}{c}\text { Native- } \\
\text { Bborn }\end{array}$ & $\begin{array}{l}\text { Common- } \\
\text { wealth: } \\
\text { India }\end{array}$ & $\begin{array}{l}\text { Common- } \\
\text { wealth: } \\
\text { Africa and } \\
\text { Caribbean }\end{array}$ & $\begin{array}{c}\text { Common- } \\
\text { wealth: } \\
\text { Pakistan / } \\
\text { Bangla- } \\
\text { desh }\end{array}$ & $\begin{array}{c}\text { EU - } \\
\text { countries }\end{array}$ & $\begin{array}{l}\text { Western } \\
\text { Industri- } \\
\text { alized } \\
\text { Countries }\end{array}$ & $\mid \begin{array}{c}\text { Other } \\
\text { Nnon- } \\
\text { Iindigenou } \\
\mathrm{s}\end{array}$ & \\
\hline & \multicolumn{10}{|c|}{ Relative Income Position $($ Total $=100)$} \\
\hline $\begin{array}{l}\text { Pre-Government } \\
\text { Income }\end{array}$ & 100 & 101 & 79 & 101 & 70 & 42 & 116 & 131 & 126 & 100 \\
\hline . Employment Income & 100 & 99 & 80 & 95 & 72 & 40 & 115 & 131 & 123 & 100 \\
\hline . Capital Income & 99 & 103 & 56 & 162 & 47 & 53 & 118 & 133 & 114 & 100 \\
\hline Private Transfers & 87 & 193 & 212 & 19 & 130 & 118 & 195 & 129 & 387 & 100 \\
\hline Non-Market Income & 100 & 96 & 130 & 68 & 159 & 141 & 96 & 59 & 63 & 100 \\
\hline - $\quad$ Old Age Pensions & 104 & 60 & 0 & 47 & 100 & 47 & 133 & 8 & 46 & 100 \\
\hline . Public Benefits & 99 & 104 & 157 & 72 & 171 & 161 & 88 & 69 & 67 & 100 \\
\hline $\begin{array}{l}\text { Taxes and Social Se- } \\
\text { curity Contributions }\end{array}$ & 99 & 103 & 82 & 93 & 71 & 35 & 123 & 144 & 125 & 100 \\
\hline $\begin{array}{l}\text { Post-Government } \\
\text { Income }\end{array}$ & 100 & 101 & 84 & 100 & 79 & 55 & 113 & 120 & 119 & 100 \\
\hline
\end{tabular}

West Germany

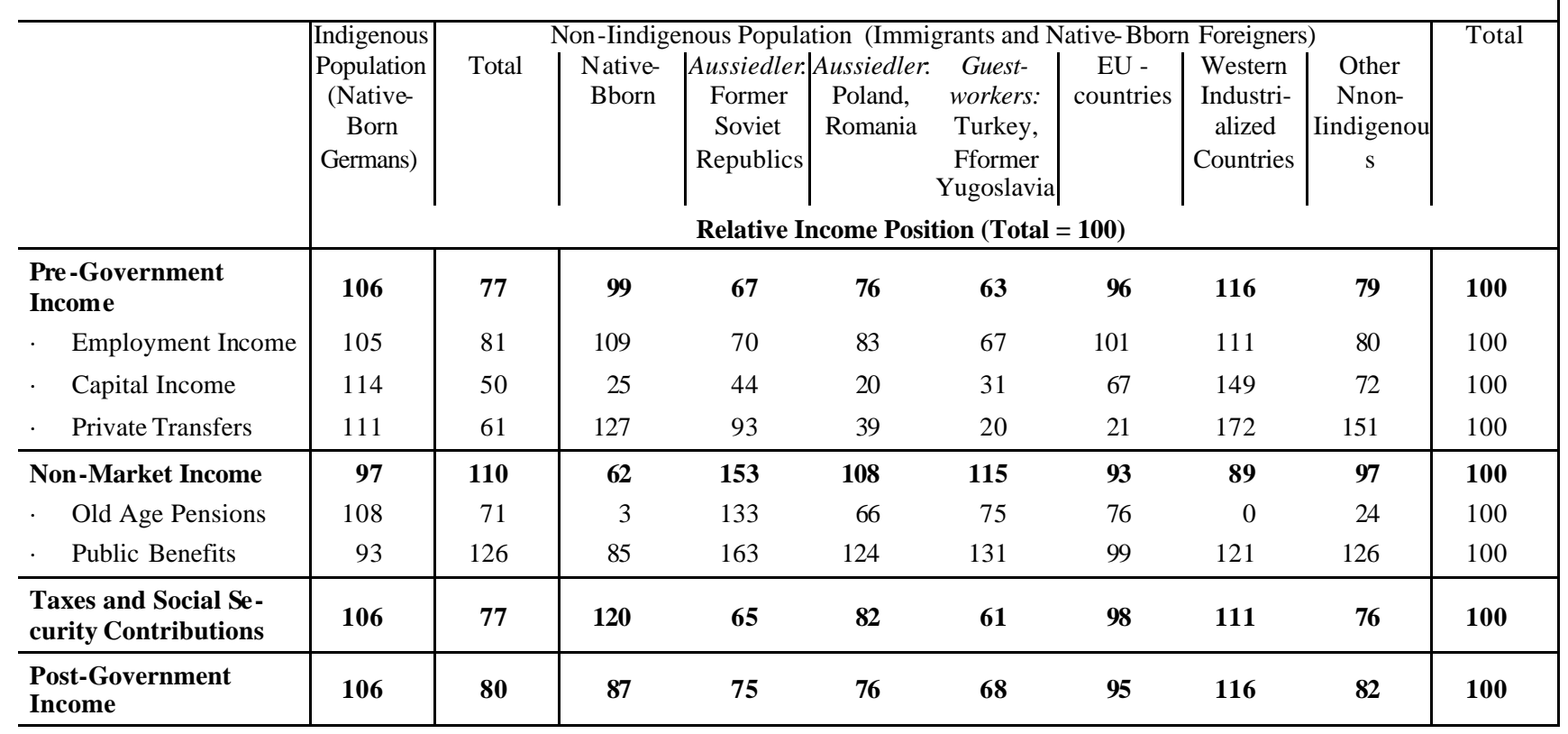

1) Average of 1994-1997 income years. - 2) Average of 1994-1998 income years.

Source: BHPS; SOEP; Cross-National Equivalent Data File; authors' calculation. 
Table 3: $\quad$ Components and Structure of Equivalent Post-Government Income in the UK, 1995-1998 ${ }^{1)}$, and in West Germany, 1995-1999²), by Ethnic Group

- Population in Private Households with Head of Prime Age -

\begin{tabular}{|c|c|c|c|c|c|c|c|c|c|c|}
\hline \multirow{4}{*}{ Income Components } & \multicolumn{9}{|c|}{ UK } & \multirow{3}{*}{ Total } \\
\hline & Indigenous & \multicolumn{8}{|c|}{\begin{tabular}{|l|l} 
Non-Iindigenous Population (Immigrants and Non-White Population) &
\end{tabular}} & \\
\hline & \begin{tabular}{|c|} 
Population \\
(Native- \\
Born \\
White \\
Pop.) \\
\end{tabular} & Total & $\begin{array}{c}\text { Native- } \\
\text { Bborn }\end{array}$ & $\begin{array}{c}\text { Common- } \\
\text { wealth: } \\
\text { India }\end{array}$ & $\begin{array}{l}\text { Common- } \\
\text { wealth: } \\
\text { Africa and } \\
\text { Caribbean }\end{array}$ & $\begin{array}{c}\text { Common- } \\
\text { wealth: } \\
\text { Pakistan / } \\
\text { Bangla- } \\
\text { desh } \\
\end{array}$ & \begin{tabular}{c|} 
EU - \\
countries
\end{tabular} & $\begin{array}{c}\text { Western } \\
\text { Industri- } \\
\text { alized } \\
\text { Countries }\end{array}$ & $\mid \begin{array}{c}\text { Other } \\
\text { Nnon- } \\
\text { Iindigenou } \\
\mathrm{s}\end{array}$ & \\
\hline & \multicolumn{10}{|c|}{ Income Component as a Proportion of Post-Government Income (in \%) } \\
\hline $\begin{array}{l}\text { Pre-Government } \\
\text { Income }\end{array}$ & 103 & 101 & 81 & 114 & 80 & 67 & 106 & 116 & 116 & 103 \\
\hline . Employment Income & 92 & 87 & 71 & 96 & 71 & 55 & 91 & 99 & 104 & 91 \\
\hline Capital Income & 10 & 10 & 6 & 17 & 5 & 8 & 12 & 14 & 10 & 10 \\
\hline Private Transfers & 2 & 3 & 5 & 1 & 3 & 4 & 3 & 2 & 2 & 2 \\
\hline Non-Market Income & 18 & 20 & 35 & 9 & 36 & 43 & 16 & 9 & 9 & 18 \\
\hline . Old Age Pensions & 2 & 1 & 0 & 1 & 1 & 2 & 1 & 0 & 1 & 1 \\
\hline Public Benefits & 16 & 19 & 35 & 9 & 35 & 41 & 15 & 9 & 8 & 17 \\
\hline $\begin{array}{l}\text { Taxes and Social Se- } \\
\text { curity Contributions }\end{array}$ & -21 & -21 & -16 & -23 & -16 & -10 & -22 & -25 & -25 & -21 \\
\hline $\begin{array}{l}\text { Post-Government } \\
\text { Income }\end{array}$ & 100 & 100 & 100 & 100 & 100 & 100 & 100 & 100 & 100 & 100 \\
\hline \multicolumn{11}{|c|}{ West Germany } \\
\hline \multirow[b]{4}{*}{$\begin{array}{l}\text { Pre-Government } \\
\text { Income }\end{array}$} & Indigenous & \multicolumn{8}{|c|}{ Non-Iindigenous Population (Immigrants and Native-Bborn Foreigners) } & \multirow[t]{2}{*}{ Total } \\
\hline & $\begin{array}{c}\text { Population } \\
\text { (Native- } \\
\text { Born } \\
\text { Germans) }\end{array}$ & Total & $\begin{array}{c}\text { Native } \\
\text { born }\end{array}$ & $\mid \begin{array}{c}\text { Aussiedler. } \\
\text { Former } \\
\text { Soviet } \\
\text { Republics }\end{array}$ & $\begin{array}{l}\text { Aussiedler: } \\
\text { Poland, } \\
\text { Romania }\end{array}$ & $\begin{array}{c}\text { Guest- } \\
\text { workers: } \\
\text { Turkey, } \\
\text { Fformer } \\
\text { Yugoslavia }\end{array}$ & \begin{tabular}{c|} 
EU - \\
countries
\end{tabular} & $\begin{array}{c}\text { Western } \\
\text { Industri- } \\
\text { alized } \\
\text { Countries }\end{array}$ & $\left|\begin{array}{c}\text { Other } \\
\text { Nnon- } \\
\text { Iindigenou } \\
\mathrm{s}\end{array}\right|$ & \\
\hline & \multicolumn{9}{|c|}{ Income Component as a Proportion of Post-Government Income (in \%) } & \\
\hline & 124 & 115 & 136 & 106 & 120 & 110 & 126 & 116 & 108 & 122 \\
\hline . Employment Income & 108 & 107 & 132 & 97 & 117 & 105 & 118 & 96 & 95 & 108 \\
\hline Capital Income & 15 & 7 & 3 & 8 & 2 & 5 & 8 & 18 & 11 & 13 \\
\hline Private Transfers & 1 & 1 & 1 & 1 & 1 & 0 & 0 & 2 & 2 & 1 \\
\hline Non-Market Income & 13 & 20 & 12 & 24 & 18 & 22 & 12 & 17 & 23 & 14 \\
\hline . Old Age Pensions & 3 & 3 & 1 & 5 & 3 & 4 & 2 & 0 & 1 & 3 \\
\hline Public Benefits & 10 & 17 & 11 & 19 & 15 & 18 & 10 & 17 & 22 & 11 \\
\hline $\begin{array}{l}\text { Taxes and Social Se- } \\
\text { curity Contributions }\end{array}$ & -37 & -35 & -48 & -30 & -38 & -32 & -38 & -33 & -31 & -36 \\
\hline $\begin{array}{l}\text { Post-Government } \\
\text { Income }\end{array}$ & 100 & 100 & 100 & 100 & 100 & 100 & 100 & 100 & 100 & 100 \\
\hline
\end{tabular}

1) Average of 1994-1997 income years. - 2) Average of 1994-1998 income years. Source: BHPS; SOEP; Cross-National Equivalent Data File; authors' calculation. 
Table 4: Household Characteristics in the UK, 1995-1998, and in West Germany, 1995-1999 - Private Households with Head of Prime Age -

\begin{tabular}{|c|c|c|c|c|}
\hline \multirow{3}{*}{ Variable } & \multicolumn{2}{|c|}{ UK } & \multicolumn{2}{|c|}{ West Germany } \\
\hline & $\begin{array}{c}\text { All Household } \\
\text { Heads of Prime } \\
\text { Age }\end{array}$ & \begin{tabular}{|c|}
$\begin{array}{c}\text { Non-Indigenous } \\
\text { Household Heads } \\
\text { of Prime Age }\end{array}$ \\
\end{tabular} & $\begin{array}{c}\text { All Household } \\
\text { Heads of Prime } \\
\text { Age }\end{array}$ & $\begin{array}{l}\text { Non-Indigenous } \\
\text { Household Heads } \\
\text { of Prime Age }\end{array}$ \\
\hline & \multicolumn{4}{|c|}{ Mean (Uunweighted, Standard Deviation in Parentheses) } \\
\hline Non-indigenous household & $.111(.313)$ & $1.000(.0)$ & $.306(.461)$ & $1.000(0)$ \\
\hline "Non-mixed" non-indigenous household & $.049(.217)$ & $.451(.497)$ & $.125(.331)$ & $.409(.491)$ \\
\hline "Mixed" non-indigenous household & $.060(.238)$ & $.548(.497)$ & $.181(.385)$ & $.590(.491)$ \\
\hline Years since migration & $2.18(7.71)$ & $19.5(14.06)$ & $5.31(9.92)$ & $17.3(10.62)$ \\
\hline$($ Years since migration $* * 2) / 100$ & $.640(2.70)$ & $5.81(6.02)$ & $1.26(2.89)$ & $4.12(3.93)$ \\
\hline Indigenous household & $.889(.313)$ & $.0(0)$ & $.693(.461)$ & $.0(0)$ \\
\hline Origin: Native- born: non-indigenous & $.017(.131)$ & $.159(.366)$ & $.021(.145)$ & $.069(.255)$ \\
\hline Origin: Commonwealth: India & $.010(.102)$ & $.096(.294)$ & - & - \\
\hline Origin: Commonwealth: Africa and Caribbean & $.007(.084)$ & $.065(.246)$ & - & - \\
\hline Origin: Commonwealth: Pakistan / Bangladesh & $.005(.072)$ & $.047(.212)$ & - & - \\
\hline Origin: Aussiedler: Former Soviet Republics & - & - & $.036(.188)$ & $.120(.325)$ \\
\hline Origin: Aussiedler: Poland, Romania & - & - & $.024(.153)$ & $.079(.269)$ \\
\hline Origin: Guest-workers: Turkey, Ex-Yugoslavia & - & - & $.117(.321)$ & $.382(.486)$ \\
\hline Origin: EU -countries & $.030(.171)$ & $.273(.445)$ & $.078(.268)$ & $.255(.436)$ \\
\hline Origin: Western iIndustrialized cCountries & $.017(.129)$ & $.155(.362)$ & $.003(.061)$ & $.011(.108)$ \\
\hline Origin: Other non-indigenous & $.022(.147)$ & $.202(.401)$ & $.024(.154)$ & $.079(.270)$ \\
\hline Single & $.159(.365)$ & $.126(.332)$ & $.176(.380)$ & $.096(.295)$ \\
\hline Couple, no children & $.247(.431)$ & $.224(.417)$ & $.236(.425)$ & $.207(.405)$ \\
\hline Couple, 1 child & $.139(.346)$ & $.150(.357)$ & $.195(.396)$ & $.228(.419)$ \\
\hline Couple, 2 children & $.141(.348)$ & $.137(.344)$ & $.160(.366)$ & $.196(.397)$ \\
\hline Couple, 3 and more children & $.064(.244)$ & $.066(.249)$ & $.062(.242)$ & $.089(.285)$ \\
\hline Single parent & $.072(.259)$ & $.093(.291)$ & $.039(.193)$ & $.031(.174)$ \\
\hline Other type of household & $.175(.380)$ & $.199(.3$ & $.129(.336)$ & $.150(.357)$ \\
\hline Age (head of household) & $40.6(10.638)$ & $40.1(10.463)$ & $40.6(10.831)$ & $41.0(11.108)$ \\
\hline$\left(\right.$ Age $\left.^{* * 2}\right) / 100$ (head of household) & $17.6(8.735)$ & $17.1(8.438)$ & $17.6(9.075)$ & $18.0(9.269)$ \\
\hline Male head of household & $.618(.485)$ & $.574(.494)$ & $.682(.465)$ & $.759(.427)$ \\
\hline Education le & $.170(.376)$ & $.146(.354)$ & $.635(.481)$ & $.636(.480)$ \\
\hline Education le & $.454(.497)$ & $.377(.485)$ & $.235(.424)$ & $.311(.462)$ \\
\hline Education level (head of household): High & $.374(.483)$ & $.475(.499)$ & $.091(.288)$ & $.031(.175)$ \\
\hline Poor health status (head of household) & $.113(.317)$ & $.112(.316)$ & $.058(.234)$ & $.065(.246)$ \\
\hline Months in unemployment last year (Head) & $.468(2.05)$ & $.543(2.27)$ & $.824(2.686)$ & $1.279(3.326)$ \\
\hline Year of observation: 1995 & $.253(.435)$ & $.258(.438)$ & $.197(.398)$ & $.213(.409)$ \\
\hline Year of observation: 1996 & $.261(.439)$ & $.267(.442)$ & $.195(.396)$ & $.207(.405)$ \\
\hline Year of observation: 1997 & $.260(.438)$ & $.258(.438)$ & $.191(.393)$ & $.198(.399)$ \\
\hline Year of observation: 1998 & $.224(.417)$ & $.215(.411)$ & $.213(.409)$ & $.197(.398)$ \\
\hline Year of observation: 1999 & - & - & $.202(.401)$ & $.182(.386)$ \\
\hline \multicolumn{5}{|l|}{$\begin{array}{l}\text { Equivalent Income Measures } \\
\text { (in } 1995 \text { national currencies) }\end{array}$} \\
\hline $\begin{array}{l}\text { Pre-Government Income (Labor Income; } \\
\text { Capital Income; Private Transfers) }\end{array}$ & $13,443(10,420)$ & $14,218(11,996)$ & $47,517(36,026)$ & $37,387(27,427)$ \\
\hline Taxes and Social Security Contributions & $3,033(3,166)$ & $3,252(3,608)$ & $15,282(15,484)$ & $11,952(11,253)$ \\
\hline $\begin{array}{l}\text { Non-Market Income (Old Age Pensions; Public } \\
\text { Benefits) }\end{array}$ & $1,128(2,013)$ & $978(1,719)$ & $3,427(5,864)$ & $3,673(4,866)$ \\
\hline Post-Government Income & $11,538(7,042)$ & $11,944(8,391)$ & $35,662(20,872)$ & $29,108(15,583)$ \\
\hline Number of observations & 13233 & 1458 & 19384 & 5946 \\
\hline
\end{tabular}

Source: BHPS; SOEP; Cross-National Equivalent Data File; authors' calculation. 
Table 5: $\quad$ Relative Pre-Government Income Position in the UK, 1995-1998, and in West Germany, 1995-1999:

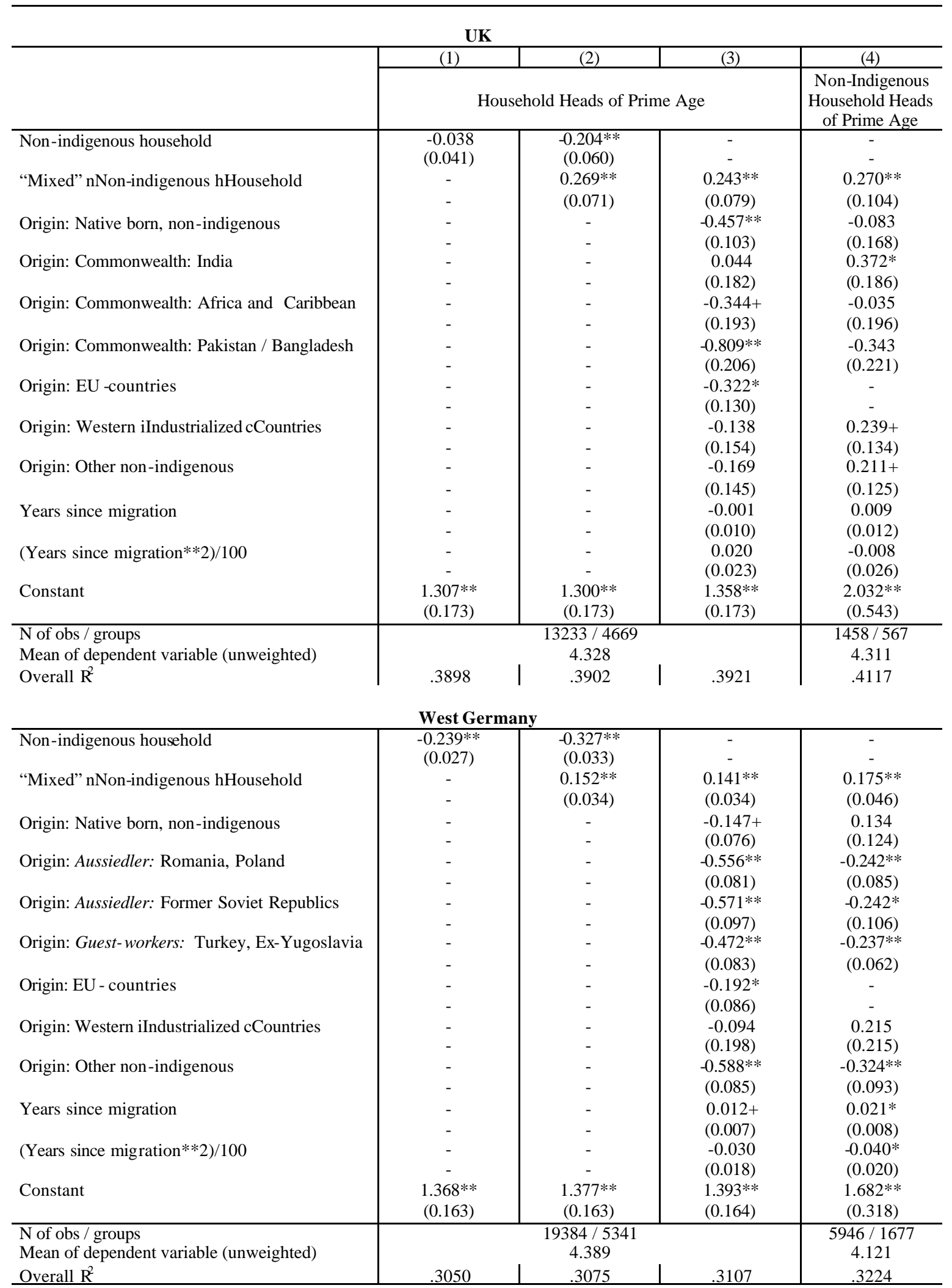

**: $\mathrm{p}<0.01 \quad *: \mathrm{p}<0.05 \quad+: \mathrm{p}<0.10$ (sStandard errors in parentheses).

Dependent Variable: log (Relative Income Position Based on Pre-Government Income)

Family structure, characteristics of head of household (age, sex, education, health status, unemployment experience), and year of observation are included in all models, but not reported here (full results are available from authors upon request).

Source: BHPS; GSOEP; Cross-National Equivalent Data File; authors' calculation. 
Table 6: $\quad$ Income Redistribution Effects in the UK, 1995 -1998, and in West Germany, 1995-1999:

Results from Random - Effects GLS Models

- Population in Private Households with Head of Prime Age -

\begin{tabular}{|c|c|c|c|c|}
\hline \multicolumn{5}{|c|}{ UK } \\
\hline & (1) & $(2)$ & (3) & (4) \\
\hline & \multicolumn{3}{|c|}{ Household Heads of Prime Age } & $\begin{array}{l}\text { Non-Indigenous } \\
\text { Household Heads } \\
\text { of Prime Age }\end{array}$ \\
\hline Non-indigenous household & $\begin{array}{l}-1.910 \\
(1.276)\end{array}$ & $\begin{array}{c}1.055 \\
(1.856)\end{array}$ & $\begin{array}{l}- \\
-\end{array}$ & $\begin{array}{l}- \\
-\end{array}$ \\
\hline "Mixed" nNon-indigenous hHousehold & - & $\begin{array}{l}-5.009^{*} \\
(2.278)\end{array}$ & $\begin{array}{l}-4.837+ \\
(2.550)\end{array}$ & $\begin{array}{l}-6.886^{*} \\
(3.116)\end{array}$ \\
\hline Origin: Native born, non-indigenous & $\begin{array}{l}- \\
-\end{array}$ & $\begin{array}{l}- \\
-\end{array}$ & $\begin{array}{r}3.800 \\
(3.202)\end{array}$ & $\begin{array}{l}-2.674 \\
(5.033)\end{array}$ \\
\hline Origin: Commonwealth: India & $\begin{array}{l}- \\
-\end{array}$ & $\begin{array}{l}- \\
-\end{array}$ & $\begin{array}{r}3.376 \\
(5.703)\end{array}$ & $\begin{array}{l}-1.000 \\
(5.538)\end{array}$ \\
\hline Origin: Commonwealth: Africa and Caribbean & $\begin{array}{l}- \\
-\end{array}$ & $\begin{array}{l}- \\
-\end{array}$ & $\begin{array}{c}3.324 \\
(6.002)\end{array}$ & $\begin{array}{c}0.271 \\
(5.830)\end{array}$ \\
\hline Origin: Commonwealth: Pakistan / Bangladesh & $\begin{array}{l}- \\
-\end{array}$ & $\begin{array}{l}- \\
-\end{array}$ & $\begin{array}{c}6.842 \\
(6.456)\end{array}$ & $\begin{array}{l}1.877 \\
(6.617)\end{array}$ \\
\hline Origin: EU -countries & $\begin{array}{l}- \\
-\end{array}$ & $\begin{array}{l}- \\
-\end{array}$ & $\begin{array}{c}5.801 \\
(4.234)\end{array}$ & $\begin{array}{l}- \\
-\end{array}$ \\
\hline Origin: Western iIndustrialized cCountries & $\begin{array}{l}- \\
-\end{array}$ & $\begin{array}{l}- \\
-\end{array}$ & $\begin{array}{l}-1.702 \\
(4.928)\end{array}$ & $\begin{array}{l}-7.177+ \\
(3.984)\end{array}$ \\
\hline Origin: Other non-indigenous & $\begin{array}{l}- \\
-\end{array}$ & $\begin{array}{l}- \\
-\end{array}$ & $\begin{array}{c}5.976 \\
(4.692)\end{array}$ & $\begin{array}{l}-2.134 \\
(3.725)\end{array}$ \\
\hline Years since migration & $\begin{array}{l}- \\
-\end{array}$ & $\begin{array}{l}- \\
-\end{array}$ & $\begin{array}{l}-0.055 \\
(0.334)\end{array}$ & $\begin{array}{l}-0.250 \\
(0.361)\end{array}$ \\
\hline$($ Years since migration $* * 2) / 100$ & - & $\begin{array}{l}- \\
-\end{array}$ & $\begin{array}{l}-0.401 \\
(0.729)\end{array}$ & $\begin{array}{c}0.387 \\
(0.782)\end{array}$ \\
\hline Constant & $\begin{array}{c}83.478^{* *} \\
(5.463)\end{array}$ & $\begin{array}{c}83.611 * * \\
(5.462) \\
\end{array}$ & $\begin{array}{c}82.895^{* * *} \\
(5.476)\end{array}$ & $\begin{array}{c}60.774 * * \\
(16.306)\end{array}$ \\
\hline $\begin{array}{l}\mathrm{N} \text { of obs / groups } \\
\text { Mean of dependent variable (unweighted) }\end{array}$ & \multicolumn{3}{|c|}{$\begin{array}{c}13233 / 4669 \\
-17.498\end{array}$} & $\begin{array}{c}1458 / 567 \\
-20.854\end{array}$ \\
\hline Overall $\mathrm{R}^{2}$ & .2662 & .2669 & .2681 & .2857 \\
\hline
\end{tabular}

Overall $\mathrm{R}^{2}$

West Germany

Non-indigenous household

"Mixed" nNon-indigenous hHousehold

Origin: Native born, non-indigenous

Origin: Aussiedler: Romania, Poland

Origin: Aussiedler: Former Soviet Republics

Origin: Guest-workers: Turkey, Ex-Yugoslavia

Origin: EU -countries

Origin: Western iIndustrialized cCountries

Origin: Other non-indigenous

Years since migratio $\mathrm{n}$

(Years since migration**2)/100

Constant

$\mathrm{N}$ of obs / groups

Mean of depende nt variable (unweighted)

Overall $\mathrm{R}^{2}$

$2.693 * *$

(0.907)

**: $\mathrm{p}<0.01 \quad *: \mathrm{p}<0.05 \quad+: \mathrm{p}<0.10$ (Standard errors in parentheses).

Dependent vVariable: Absolute change in rRelative iIncome pPosition due to rRedistribution

Family structure, characteristics of head of household (age, sex, education, health status, unemployment experience), and year of observation are included in all models, but not reported here (full results are available from authors upon request).

Source : BHPS; Cross-Nat ional Equivalent Data File; authors' calculation. 


\section{Endnotes}

1 We are most grateful to Stephen Jenkins, who provided us with a with the BHPS income data required for our analysis. Furthermore, we thank three anonymous referees for most valuable comments.

2 Studies focusing on this issue constitute a major field of research in the context of immigration. The general expectation is that take-up intensity among immigrants will decrease with increasing duration of stay. However, a contradictory result has been presented by Baker and Benjamin (1995). This might be explained by differing institutional settings across the countries in which these studies were conducted. Borjas \& Hilton (1996) believe that social networks among immigrants lead to higher take-up rates in this group. This interpretation is challenged by Zavodny (1997), however. Voges, Frick, and Büchel (1998) as well as Castranova et al. (2001) state that welfare receipt is higher among immigrants than among the native population, and the latter even find that take-up rates among immigrants are above average in the case of eligibility. However, both studies conclude that these findings can be attributed to the less favourable social structure of immigrant populations, i.e., that different ethnic origin is not a risk factor per se.

3 Backed up by the United Nations Population Division (2000) report stressing the need for immigration to Germany in order to combat the demographic problems of the ageing country, German politicians have recently started to think more carefully about another paradigm change. After an Expert Commission on Immigration (Zuwanderungs Kommission) presented its suggestions for a new immigration law in the early summer of 2001, the German parliament passed an innovative immigration law in spring 2002. Core elements of the new law are that the number of people allowed to immigrate will be regulated by specific labour market demands (e.g., the "Green Card" regulation), and that immigration should be more selective with respect to the socio-economic structure of the future immigrant population.

4 This annual income information is drawn from the Cross-National Equivalent File (CNEF, see Burkhauser et al. 2001). Since the GSOEP only collects information on gross income, a simulation module is used in the SOEP section of the CNEF to calculate individual tax and social security contributions and, finally, post-government income. This simulation only takes progression rules and basic allowances into account (cf. Schwarze 1995). Given that potential tax exemptions--which are very often concentrated at the upper tail of the income distribution--are largely overlooked, it may overestimate real tax payments

5 The age structure of ethnic groups (and hence the proportion of older people per ethnic group) is strongly dependent on groupspecific immigration patterns. In addition, group-specific differential mortality can also be expected to affect redistribution patterns (Creedy et al. 1993).

6 Descriptive results covering the full sample are available from the authors upon request.

$7 \quad$ As Bell (1997) and Shields \& Wheatley Price (1998) point out, it is important to differentiate between native-born and foreignborn immigrants in this context.

8 We are aware that immigrants from the Caribbean to the UK generally perform better in economic terms than those from Africa. However, the relatively low number of cases in these sub-groups of black immigrants makes poolingnecessary.

$9 \quad$ This trimming reduced the number of observations by about 150 in both data sets. It should be noted that the providers of both data sets put much effort in to imputing income information that is missing due to item non-response: for information on the regressionbased imputation technique used in the BHPS, see http://www.iser.essex.ac.uk/bhps/doc/index.html [Section V]; for the SOEP application of the rowand-column imputation procedure proposedby Little \& Su (1989), see Butrica 1997.

10 Private transfers are by definition non-negative, since the underlying data does not account for transfers made to other private households.

11 For Germany, public transfers include housing benefits, child benefits, subsistence allowances and special circumstances benefits from the Social Welfare Authority, student grants, maternity benefits, unemployment benefits, unemployment relief, and unemployment subsistence allowance. For the UK, our measure of public transfers is based on detailed information on different types of social security benefits received by each member of a given household. However, the structure of housing benefits is somewhat different in wave 1 than thereafter (see Bardasi et al. 1999, p. 19).

12 These results can in part be attributed to the inclusion of imputed rental value for owner-occupied housing in our measure of capital income (as suggested by Smeeding \& Weinberg, 2001). Not surprisingly, the proportion of owner-occupiers is by far the highest in the indigenous population. It should be noted that the inclusion of imputed rent in our income measure does not change the principal structure depicted here; rather, it accentuates the overall results.

13 As is the case for the UK, it should be borne in mind that the households of native-born foreigners in Germany are younger (average age of head: 35 years; not documented in tables) than in any other immigrant group (43 years) or indeed in the indigenous population (41 years).

14 We are aware that some regressors could be endogenous. This problem is inevitable in research designs such as ours. We therefore regard our approach as a correlation analysis rather than a causal one.

15 We assume equal effects of the socio-economic characteristics across ethnic groups. To test the accuracy of this assumption, we re-ran all models using terms of interaction for "education" and "ethnic group". The results remained very stable (results of this variant are available from the authors upon request). 


\section{IZA Discussion Papers}

\begin{tabular}{|c|c|c|c|c|}
\hline No. & Author(s) & Title & Area & Date \\
\hline 773 & A. Heitmueller & $\begin{array}{l}\text { Job Mobility in Britain: Are the Scots Different? } \\
\text { Evidence from the BHPS }\end{array}$ & 1 & $05 / 03$ \\
\hline 774 & $\begin{array}{l}\text { A. Constant } \\
\text { D. S. Massey }\end{array}$ & $\begin{array}{l}\text { Labor Market Segmentation and the Earnings of } \\
\text { German Guestworkers }\end{array}$ & 1 & $05 / 03$ \\
\hline 775 & $\begin{array}{l}\text { J. J. Heckman } \\
\text { L. J. Lochner } \\
\text { P. E. Todd }\end{array}$ & Fifty Years of Mincer Earnings Regressions & 5 & $05 / 03$ \\
\hline 776 & $\begin{array}{l}\text { L. Arranz-Aperte } \\
\text { A. Heshmati }\end{array}$ & $\begin{array}{l}\text { Determinants of Profit Sharing in the Finnish } \\
\text { Corporate Sector }\end{array}$ & 2 & $05 / 03$ \\
\hline 777 & $\begin{array}{l}\text { A. Falk } \\
\text { M. Kosfeld }\end{array}$ & $\begin{array}{l}\text { It's all about Connections: Evidence on Network } \\
\text { Formation }\end{array}$ & 6 & $05 / 03$ \\
\hline 778 & F. Galindo-Rueda & $\begin{array}{l}\text { Employer Learning and Schooling-Related } \\
\text { Statistical Discrimination in Britain }\end{array}$ & 5 & $05 / 03$ \\
\hline 779 & M. Biewen & $\begin{array}{l}\text { Who Are the Chronic Poor? Evidence on the } \\
\text { Extent and the Composition of Chronic Poverty } \\
\text { in Germany }\end{array}$ & 1 & $05 / 03$ \\
\hline 780 & $\begin{array}{l}\text { A. Engellandt } \\
\text { R. T. Riphahn }\end{array}$ & Temporary Contracts and Employee Effort & 1 & $05 / 03$ \\
\hline 781 & $\begin{array}{l}\text { J. H. Abbring } \\
\text { J.R. Campbell }\end{array}$ & $\begin{array}{l}\text { A Structural Empirical Model of Firm Growth, } \\
\text { Learning, and Survival }\end{array}$ & 5 & $05 / 03$ \\
\hline 782 & $\begin{array}{l}\text { M. Güell } \\
\text { B. Petrongolo }\end{array}$ & $\begin{array}{l}\text { How Binding Are Legal Limits? Transitions from } \\
\text { Temporary to Permanent Work in Spain }\end{array}$ & 1 & $05 / 03$ \\
\hline 783 & $\begin{array}{l}\text { B. T. Hirsch } \\
\text { E. J. Schumacher }\end{array}$ & $\begin{array}{l}\text { Match Bias in Wage Gap Estimates Due to } \\
\text { Earnings Imputation }\end{array}$ & 5 & $05 / 03$ \\
\hline 784 & $\begin{array}{l}\text { O. Pierrard } \\
\text { H. R. Sneessens }\end{array}$ & $\begin{array}{l}\text { Low-Skilled Unemployment, Biased } \\
\text { Technological Shocks and Job Competition }\end{array}$ & 2 & $05 / 03$ \\
\hline 785 & R. Almeida & $\begin{array}{l}\text { The Effects of Foreign Owned Firms on the } \\
\text { Labor Market }\end{array}$ & 2 & $05 / 03$ \\
\hline 786 & $\begin{array}{l}\text { P. Mueser } \\
\text { K. R. Troske } \\
\text { A. Gorislavsky }\end{array}$ & $\begin{array}{l}\text { Using State Administrative Data to Measure } \\
\text { Program Performance }\end{array}$ & 6 & $05 / 03$ \\
\hline 787 & $\begin{array}{l}\text { P. Garibaldi } \\
\text { L. Pacelli } \\
\text { A. Borgarello }\end{array}$ & $\begin{array}{l}\text { Employment Protection Legislation and the Size } \\
\text { of Firms }\end{array}$ & 3 & $05 / 03$ \\
\hline 788 & $\begin{array}{l}\text { F. Büchel } \\
\text { J. R. Frick }\end{array}$ & $\begin{array}{l}\text { Immigrants in the UK and in West Germany - } \\
\text { Relative Income Position, Income Portfolio, and } \\
\text { Redistribution Effects }\end{array}$ & 1 & $06 / 03$ \\
\hline
\end{tabular}

An updated list of IZA Discussion Papers is available on the center's homepage www.iza.org. 